\title{
特集 呼吸器領域の新しい薬物療法：作用機序と使用の実際
}

\section{トレーニング問題}

1. 抗IgE抗体療法の効果で正しいのはどれか. 1 つ選べ.
(a) IgE遮断抗体の産生
（b）炎症性メディエータの枯渇
(c) 抗原特異的減感作
(d) $\operatorname{IgE}$ 受容体の減少
(e) Free IgEの増加

2. 吸入ステロイド薬（ICS）と長時間作用性吸入 $\beta_{2}$ 刺激薬（LABA）の配合䨩について正しい ものはどれか. 2 つ選べ.
（a）ICSとLABAを別々に併用するよりも有効性が高い.
（b）ICSとLABAを別々に併用するよりも副作用の発生頻度が高い.
(c) ICSとロイコトリエン受容体拮抗薬の併用療法と有効性は同等である.
（d）患者は，配合剤吸入初日より効果を実感する.
（e）配合剤での治療により約 $30 \%$ の喘息患者でガイドラインの目指すコントロールが可能で ある。

3. 肺動脈性肺高血圧症（PAH）の薬物療法について正しいのはどれか. 1 つ選べ.
（a）WHO機能分類クラスIIIから治療適応となる.
（b）最初はカルシウム拮抗薬を投与する.
(c) 膠原病に伴うPAHではエンドセリン受容体拮抗薬の適応はない.
（d）エンドセリン受容体拮抗薬は生存率を改善させることはない.
（e）単剤で治療効果不良の場合は併用療法を行う.

4. 肺動脈性肺高血圧症に対するホスホジエステラーゼ (PDE) 5 阻害薬治療について正しいも のはどれか. 1 つ選べ.
（a）他の血管拡張薬との併用は禁忌である.
（b）心筋収縮力を増強する.
(c) 長期間連用によって効果は減弱する.
（d）亜硝酸製剂との併用で著しい高血圧発作をきたす.
（e）エポプロステロールとの併用で生存が延長する. 
5. プロスタサイクリン (PGI2) 誘導体の作用について間違っているものはどれか. 1 つ選べ.
(a) 血管拡張作用
（b）血管内皮細胞保護作用
(c) エンドセリン拮抗作用
（d）血小板凝集抑制作用
（e）血管平滑筋細胞の増殖抑制作用

6. RBT投与について正しいのはどれか. 1 つ選べ.
（a）RBTはRFPよりCYP3A4 誘導作用は強いと報告されている.
（b）RBTはクラリスロマイシン併用時に血中濃度が低下するので，増量する.
(c) RBT投与時は腎障害の程度で投与量を減少する.
（d）RBTは抗HIV薬と併用時に血中濃度が変化する薬剤はない.
(e) RBTは小児への投与も可能である.

7. ノイラミニダーゼ阻害作用を有する抗インフルエンザ薬はどれか. 2 つ選べ.
(a) アマンタジン
(b) リバビリン
(c) ザナミビル
(d) オセルタミビル
（e）ガンシクロビル

8. 2009 年に出現したパンデミックインフルエンザウイルスは次のどれと近似するウイルスか. 1 つ選べ.
（a）スペインかぜウイルス
（b）アジアかぜウイルス
（c）ソ連かぜウイルス
（d）香港かぜウイルス
(e) SARSコロナウイルス

9. 抗真菌薬について正しいのはどれか. 1 つ選べ.
（a）フルコナゾールはアスペルギルス感染症に無効である.
（b）ボリコナゾールは通常, 負荷投与（loading dose）が必要でない.
（c）イトラコナゾール内用液は妊婦に使用できる.
（d）ミカファンギンは腎機能低下時に投与量を減ずる必要がある.
（e）アムホテリシンBリポソーム製剤の投与は 24 時間持続点滴注射が望ましい. 
10. ペメトレキセドによる治療が標準療法とされる肺縦隔原発悪性腫瘍の組織型として, 適切な ものはどれか. 2 つ選べ.
(a) 肺扁平上皮癌
（b）悪性胸膜中皮腫
(c) 肺腺癌
(d) 肺小細胞癌
(e) 胸腺癌

11. ARDS（急性呼吸促迫症候群）の治療・管理について正しいのはどれか. 1 つ選べ.

(a) 副腎皮質ステロイドにより生存率が改善することは，大規模臨床試験で証明されている.

（b）シベレスタットは, 好中球からの活性酸素種の放出を阻害することにより治療効果が期待 されている。

（c）肺コンプライアンスが低下しているため，一回換気量を高く設定し，肺の伸展をはかる.

（d）早期から経腸栄養を基本とした栄養療法を開始することが望ましい.

（e）水分管理を厳格に行うため，肺動脈カテーテルの挿入がつよく推奨されている.

12. リンパ脈管筋腫症で通常みられないものはどれか. 1 つ選べ.
(a) 血痰
(b) 血胸
(c) 乳糜胸水
(d) 呼吸不全
(e) 閉塞性換気障害

13. シロリムスについて正しいものはどれか. 2 つ選べ.
（a）免疫抑制剂であるとともに，細胞増殖も抑制する.
（b）カルシニューリンと結合して，mTORを阻害する.
(c) 口内炎や高脂血症は副作用として頻度が高い.
（d）内服中でも妊娠してもよい.
（e）主として腎藏から排泄される. 


\section{解答と解説}

問題 1

解答 : (d)

解説

抗IgE抗体療法は, 機能的に遮断抗体として作 用し，炎症性メディエータの遊離を抑制し，抗 原非特異的にIgE分子のC 33 に結合し, free $\operatorname{IgE}$ に結合することでfree IgEを減少させる．Free $\operatorname{IgE}$ の減少は, その結合部位である $\operatorname{IgE}$ 受容体の 減少を来たす。したがって，正しいのは（d）で ある。

\section{問題 2}

解答：(a)，(d)

解説

ICSとLABAの配合剂は, 相乗的に作用するこ とが報告されており，別々に併用するよりも有 効性が高い。 また, 副作用の発現頻度は, ICS 単剂あるいはLABA単郕と同等であり, かつ配合 剂特有の副作用は認めない. 配合剂をICSとテオ フィリン徐放製剂の併用療法と比較した試験や, 配合剂をICSとロイコトリエン受容体拮抗薬の併 用療法と比較した試験において，配合剂の方が 有効性において優れていた. ICS単郕では, 患者 が効果を実感するのに 1 週間位要するが, 配合 剂では投与初日より効果を実感する。配合剂で の治療により $70 \%$ 以上の喘息患者でガイドライ ンの目指すコントロールが可能である.

\section{問題 3}

解答 : (e)

解説

肺動脈性肺高血圧症 (pulmonary arterial hypertension : PAH）の治療は, 血管拡張薬の 投与が基本となる. 現在使用可能な血管拡張薬 は, カルシウム拮抗薬, プロスタサイクリン誘 導体薬, エンドセリン受容体拮抗薬および phosphodiesterase-5 (PDE-5) 阻害薬である。 カ ルシウム拮抗薬は, 基本的に急性肺血管反応試 験陽性の特発性および遺伝性PAHが適応となる. PAHの薬物療法はWHO機能分類クラスIIから推 奨されており,クラスII・IIIではエンドセリン受 容体拮抗薬やPDE-5 阻害薬が中心となる. エン ドセリン受容体拮抗薬は, 特発性および遺伝性 $\mathrm{PAH}$ と膠原病に伴うPAHに対する有効性が確立 しており, 生存率を改善させる.また，単独の 血管拡張薬で治療効果不良の場合は, 他系統の 薬剂との併用療法に移行する.

\section{問題 4}

解答 : (e)

解説

（a）併用による効果増強，持続延長が期待さ れている. 薬物代謝の面から効果の減弱が懸念 されたボセンタンとの併用も試みられている.

(b) PDE3 阻害薬milrinoneは心筋収縮力を増 強させる心不全の治療薬

(c) Prostanoidであるべラプロストは効果の減 弱がおこりうるが, PDE5 阻害薬では一般的では ない.

（d）併用でcGMPの作用が増強しすぎて，血圧 の著しい低下と頻拍発作をきたすことがある．

（e）本文（1557 ページ）参照. RCTによる有 用性の検討あり。

\section{問題 5}

解答 : (c)

解説

プロスタサイクリン（PGI2）は, PGI2 受容体 に結合し,アデニートサイクラーゼを活性化し, cAMPを上昇させることで薬理作用を発揮する. 具体的には血管拡張作用, 血小板凝集抑制作用, 血管平滑筋の増殖抑制作用などを有する.また， 
今までの基礎研究より血管内皮細胞の内皮障害 に対する保護作用も確認されている。 しかし， 血管収縮に加えて血管平滑筋細胞増殖や線維化 誘導, 接着分子発現を増加するエンドセリンに は作用しないといわれている.

\section{問題 6}

解答 : (c)

解説

（a）× RBTはリファマイシン系に属し, RFP とともにCYP3A4 誘導をするが, RFPよりその 作用は弱い.

（b） × RBTはクラリスロマイシンとの併用 時, ブドウ膜炎などの副作用が増強するため, 増量はしない。

（c） $\bigcirc$ RBTはCcrの值によって投与量を減量 する.

(d) $\times$ 抗HIV薬投与時相互作用にて血中濃度 の変動があるため, 一剂ごとに確認する必要が ある。

（e）× RBTは若年者投与に経験がなく，小 児への投与は行わないことを原則とする.

\section{問題 7}

解答：(c)，(d)

\section{解説}

（a）から（d）までは抗インフルエンザ薬であ るが, アマンタジンはA型インフルエンザウイル スが宿主細胞内に侵入した後にM2 蛋白の活性を 阻害することによって脱款する過程を阻害する 薬剤であり,リバビリンはRNA合成を阻害して ウイルスの複製を阻害する薬片である。（e）の ガンシクロビルはサイトメガロウイルスに作用 する薬剤である。

\section{問題 8}

解答 : (a)

解説

インフルエンザウイルスは, ウイルス表面に
有する 2 種類のスパイクであるへムアグルチニ ン（HAまたはHと略する）とノイラミニダーゼ (NAまたはNと略する)の抗原性の相違によって 幾つかの亜型に分類されるが，（a）から（d）の 4 種のウイルスがインフルエンザウイルスである. （a）はH1N1，（b）はH2N2，（c）はH1N1，（d） はH3N2 であるが, 2009 年に出現したパンデミッ クインフルエンザウイルスはH1N1 亜型のうち （a）のスペインかぜウイルスとの相同性が大き い.

\section{問題 9}

解答 : (a)

解説

（a）フルコナゾールはアスペルギルス感染症 に無効である。正しい.

（b）ボリコナゾールをはじめとしたアゾール 系抗真菌薬の臨床効果は, AUC/MICと相関する ため，投与初期に負荷投与 (loading dose) を行 うことが推奨される.

（c）イトラコナゾール内用液を含むアゾール系 抗真菌薬は, 妊婦に対しては禁忌である.

（d）ミカファンギンの使用において，腎障害 はdose limiting factorとはならず, 腎機能低下患 者においても，常用量の使用が認められる.

(e) アムホテリシンBの臨床効果はAUC/MIC またはPeak/MICに相関するため, 1 回投与量を 増やし，なるべく短時間で投与する方法が望ま しい.

\section{問題 10}

解答：(b)，(c)

解説

新規葉酸代謝拮抗薬であるぺメトレキセドは, 第III相試験においてシスプラチンと併用する治 療法により有効性を証明された, 悪性胸膜中皮 腫に対する標準薬として知られる。 また非小細 胞肺癌に対しては組織型によって有効性が異な るという特徵を有し，現在腺癌を含めた非扁平 
上皮癌における標準療法に用いられる薬剤の一 つとなっている．肺小細胞癌や胸腺癌に対する エビデンスは存在しない.

\section{問題 11}

解答 : (d)

\section{解説}

（a）副腎皮質ステロイドによりARDS患者の酸 素化が改善するとの報告はあるが, 大規模臨床 試験で生存率の改善が示されたことはない.

（b）シベレスタットは好中球エラスターゼの 特異的阻害薬である.

(c) 一回換気量を $12 \mathrm{ml} / \mathrm{kg}$ (予測体重), 吸気 終末プラトー圧を $50 \mathrm{cmH}_{2} \mathrm{O}$ 以下にする従来の呼 吸管理と比較して, 一回換気量を $6 \mathrm{ml} / \mathrm{kg}$ (予測 体重）と低めに設定し，吸気終末プラトー圧を $30 \mathrm{cmH}_{2} \mathrm{O}$ 以下に保つ呼吸管理が有意に入院死亡 率を低下させることが示されている.

（d）正答. 中心静脈栄養を長期間行っている と, 腸粘膜の絨毛の萎縮などが起こり, 腸内細 菌やそれに由来する毒素が腸管外へ移行するよ うになる。これをbacterial translocationと呼び, 病態を増悪させると考えられている.

（e）ARDSでは, 循環動態が安定している限り 水分制限・利尿剂投与を行い, 水分バランスを 保つことで蔵器不全発生頻度の低下, 呼吸機能 の改善が得られる。ただし肺動脈カテーテルを 挿入して水分管理を行うことでは予後が改善せ ず,また不整脈や感染などの合併症も多いため, 肺動脈カテーテルの挿入は推奨されていない.

\section{問題 12}

解答 : (b)

解説

若い女性で血痰を主要症状の一つとすること
は是非記憶して欲しいが, 血胸はほとんどない. LAMは若い女性の気胸の基礎疾患として重要な 疾患である. 主要症状の中では労作性の息切れ に次いで, 気胸は頻度が高い.

\section{問題 13}

解答 : (a), (c)

\section{解説}

シロリムスはFKBP12 と結合して複合体とな り, mTORを阻害する. シロリムスはカルシニュー リンを阻害することで免疫抑制作用を示すタク ロリムスやシクロスポリンとは異なる免疫抑制 骺である. シロシムス内服中は避妊が必要であ る. 肝蔵や小腸壁のCYP3A4 やP-gpで代謝され, そのほとんどは粪便中に排泄される．従って， 肝機能障害時, CYP3A4 やP-gpに影響する薬剤 との相互作用により血中濃度は影響を受ける.

\section{[問題作成者]}

帝京大学医学部呼吸器・アレルギー内科

大田 健

昭和大学呼吸器・アレルギー内科廣瀬敬 信州大学医学部内科学第一講座 花岡 正幸 奈良県立医科大学内科学第二講座 木村 弘 東京慈恵会医科大学附属病院薬剤部医薬品情報室 北村 正樹 国立病院機構千葉東病院呼吸器科佐々木結花 東北大学加齢医学研究所抗感染症薬開発研究部門

$\begin{array}{lrr} & \text { 渡辺 } & \text { 彰 } \\ \text { 長崎大学医学部第二内科 } & \text { 泉川 } & \text { 公一 } \\ \text { 九州大学医学研究院胸部疾患研究施設 } & & \end{array}$
慶應義塾大学医学部内科学教室田坂 定智 順天堂大学医学部呼吸器内科瀬山 邦明 